\title{
DISTRIBUTION OF EXTRACTABLE CALCIUM, MAGNESIUM, POTASSIUM, AND SODIUM IN VARIOUS DEPTHS OF SOME VIRGIN PEAT SOILS
}

\author{
Armi Kaila and JaAkKo Kivekäs \\ Department of Agricultural Chemistry, University of Helsinki
}

Received August 7, 1956.

The distribution of plant nutrients in various layers of a peat profile depends on several factors. Among these are for example the intensity with which the nutrients are adsorbed or fixed by the peat, the quantities of nutrients carried by the water or by the air from the neighbourhood, and also the utilization of nutrients by the respective surface vegetation. In shallow peat lands the quality of the mineral subsoil is of importance, too.

Our information even of the combined effect of all these factors on the nutrient content of various peat layers is rather poor. Only very few results concerning this problem are reported in Finland. In a previous publication one of us (2) tried to elucidate the distribution and forms of phosphorus in various depths of thirty virgin peat lands. WARÉN (4) gives data of calcium, magnesium, potassium, phosphorus and sulphur soluble in $4 \%$ hydrochloric acid from nine peat profiles. In addition to these only some scattered reports exist.

The authors were interested in the contents of plant available calcium, magnesium and potassium in various depths of peat lands. Therefore, an investigation was carried out in which samples from different layers of virgin peat soils were analysed, generally down to about a depth of one meter. The extraction with ammonium chloride solution was supposed to give an estimate of the available amounts of the cations. In addition to calcium, magnesium, and potassium also sodium was determined. 


\section{Material and methods}

The material of the present investigation consisted of 85 samples taken from 25 peat lands. All of them were from Northern Finland and represented uncultivated soils. The surface vegetation type and degree of land quality of the sampling places were the following:

1. Sphagnum fuscum pine bog, Bo 1 .

2. Treeless Sphagnum fuscum bog, Bo 1.

3. - 4. Carex globularis pine bog, Bo 2.

5. Oligotrophic water-logged Sphagnum bog occupying hollows, Bo $1-2$.

6. Treeless Sphagnum papillosum bog, Bo $1-2$.

7. - 8. Treeless Sphagnum papillosum - Scirpus caespitosus bog, Bo 2.

9. - 10. Treeless Sphagnum papillosum - Carex lasiocarpa bog, Bo 3.

11. - 15. Treeless Sphagnum papillosum - Carex limosa bog, Bo 3.

16. Mesotrophic treeless Sphagnum papillosum bog, Bo 6 .

17. - 18. As number 16, occupying hollows, Bo 5 .

19. - 20. Treeless, water-logged Carex limosa bog, Bo 4.

21. Flooded bog, without trees, Bo 5.

22. Mesotrophic water-logged treeless Carex-bog, Bo 6 .

23. Sphagnum Warnstorfianum fen, Bo 8.

24. - 25. Scorpidium scorpioides fen, Bo 7 .

The depths of the sampling layers and the kind of the respective peat are reported in Table 1 which also gives the degree of humification for the peat samples estimated in the field according to the method of von PosT (3). In addition to the peat samples also samples of mixed surface vegetation were collected from the peat lands n:ris $6-10$ and $12-18$.

All the analyses described in the present paper were performed of air-dry peat ground in a Wiley mill. The $\mathrm{pH}$-value was determined in a water suspension (1: 4).

The extraction of the cations was carried out with $1 \mathrm{~N}$ ammonium chloride solution. The ratio of soil to extractant was 1: 50 , and the extraction period was two hours. The estimation of calcium, potassium, and sodium in the filtrate was performed using the flame photometer by Lange. The total calcium + magnesium content of the filtrate was determined by the versenate titration (1) and the amount of magnesium was calculated on the basis of the calcium content estimated by the flame photometer.

Obviously, the data obtained by this method do not correspond to the content of exchangeable cations in these soils. A more reliable estimation of their amount could have been gained if barium chloride instead of ammonium chloride had been used and if the extraction had been completed by some thorough washings. The disturbing effect of barium on the flame photometric determination of the other cations prevented its employment, and it was necessary to resort to ammonium chlo- 
Table 1. Calcium, magnesium, potassium and sodium extracted by $1 \mathrm{~N}$ ammonium chloride trom various layers of the peat lands

\begin{tabular}{|c|c|c|c|c|c|c|c|c|c|c|}
\hline \multirow{2}{*}{ No } & Depth & Kind & \multirow{2}{*}{$\mathrm{H}$} & \multirow{2}{*}{$\mathrm{pH}$} & \multirow{2}{*}{$w / v$} & Ash & $\mathrm{Ca}$ & $\mathrm{Mg}$ & $\mathrm{K}$ & $\mathrm{Na}$ \\
\hline & $\mathrm{dm}$ & peat & & & & $\%$ & \multicolumn{4}{|c|}{ kg/ha } \\
\hline \multirow[t]{3}{*}{1.} & $0-3$ & $\mathrm{~S}$ & 1 & 4.2 & 0.08 & 5.9 & 660 & 180 & 30 & 20 \\
\hline & $4-6$ & $\mathrm{~S}$ & 1 & 4.4 & 0.08 & 3.9 & 750 & 150 & 10 & 10 \\
\hline & $6-8$ & $\mathrm{CS}$ & 5 & 4.5 & 0.25 & 5.8 & 220 & 450 & 30 & 10 \\
\hline \multirow[t]{3}{*}{2.} & $0-2$ & $\mathrm{~S}$ & 1 & 4.5 & 0.11 & 4.9 & 1080 & 310 & 140 & 10 \\
\hline & $2-4$ & $\mathrm{CS}$ & 2 & 4.6 & 0.23 & 5.0 & 2000 & 340 & 170 & 20 \\
\hline & $4-6$ & $\mathrm{CS}$ & 4 & 4.6 & 0.25 & 4.3 & 1750 & 270 & 70 & 10 \\
\hline \multirow[t]{3}{*}{3.} & $1-2$ & $\mathrm{~S}$ & 1 & 4.5 & 0.11 & 4.2 & 1500 & 80 & 230 & 100 \\
\hline & $2-3$ & $\mathrm{~S}$ & 2 & 4.6 & 0.17 & 4.5 & 2300 & 120 & 280 & 120 \\
\hline & $3-4$ & $\mathrm{CS}$ & 5 & 4.6 & 0.39 & 5.5 & 3000 & 150 & 210 & 80 \\
\hline \multirow[t]{3}{*}{4.} & $0-3$ & I.CS & 2 & 4.2 & 0.09 & 3.4 & 410 & 400 & 470 & 40 \\
\hline & $3-5$ & & 4 & 4.4 & 0.25 & 9.7 & 860 & 750 & 320 & 670 \\
\hline & $7-10$ & & 6 & 4.3 & 0.36 & 6.2 & 850 & 850 & 130 & 300 \\
\hline \multirow[t]{4}{*}{5.} & $0-2$ & $\mathrm{~S}$ & 1 & 3.7 & 0.05 & 1.4 & 180 & 150 & 90 & 40 \\
\hline & $2-5$ & & 3 & 3.6 & 0.09 & 1.5 & 410 & 220 & 40 & 30 \\
\hline & $5-9$ & & 5 & 3.8 & 0.21 & 2.9 & 710 & 350 & 50 & 50 \\
\hline & $9-11$ & & 7 & 4.2 & 0.32 & 2.4 & 1130 & 580 & 60 & 30 \\
\hline \multirow[t]{4}{*}{6.} & \multicolumn{2}{|c|}{ Plant matter } & & 4.3 & 0.07 & 7.2 & 350 & 320 & 490 & 30 \\
\hline & $0-2$ & $\mathrm{~S}$ & 1 & 3.9 & 0.29 & 5.7 & 1200 & 1000 & 150 & 10 \\
\hline & $3-5$ & $\mathrm{~S}$ & 3 & 4.0 & 0.34 & 4.0 & 1000 & 580 & 30 & 10 \\
\hline & $8-10$ & $\mathrm{SC}$ & 5 & 4.1 & 0.30 & 3.1 & 780 & 410 & 20 & 0 \\
\hline \multirow[t]{4}{*}{7.} & \multicolumn{2}{|c|}{ Plant matter } & & 4.4 & 0.06 & 6.9 & 280 & 190 & 310 & 40 \\
\hline & $0-3$ & $\mathrm{~S}$ & 1 & 4.5 & 0.12 & 5.2 & 480 & 350 & 10 & 10 \\
\hline & $5-7$ & $\mathrm{CS}$ & 4 & 4.3 & 0.30 & 3.5 & 960 & 660 & 10 & 20 \\
\hline & $8-10$ & CS & 5 & 4.1 & 0.35 & 4.0 & 1260 & 850 & 10 & 10 \\
\hline \multirow[t]{3}{*}{8.} & \multicolumn{2}{|c|}{ Plant matter } & & 4.3 & 0.10 & 5.8 & 480 & 240 & 740 & 150 \\
\hline & $1-3$ & $\mathrm{CS}$ & 3 & 3.8 & 0.33 & 7.8 & 1000 & 280 & 140 & 70 \\
\hline & $3-5$ & $\mathrm{SC}$ & 7 & 4.2 & 0.42 & 11.0 & 920 & 280 & 60 & 40 \\
\hline \multirow[t]{3}{*}{9.} & \multicolumn{2}{|c|}{ Plant matter } & & 4.5 & 0.07 & 7.9 & 620 & 320 & 620 & 30 \\
\hline & $0-2$ & $\mathrm{~S}$ & 1 & 4.4 & 0.28 & 10.8 & 1800 & 780 & 360 & 20 \\
\hline & $3-5$ & $\mathrm{C}$ & 3 & 4.5 & 0.29 & 10.0 & 1200 & 500 & 110 & 20 \\
\hline \multirow[t]{3}{*}{10.} & \multicolumn{2}{|c|}{ Plant matter } & & 4.5 & 0.09 & 8.5 & 620 & 360 & 760 & 130 \\
\hline & $1-3$ & $\mathrm{SC}$ & 4 & 4.3 & 0.34 & 6.2 & 1800 & 350 & 240 & 200 \\
\hline & $3-5$ & $\mathrm{LC}$ & 7 & 4.6 & 0.31 & 5.3 & 1300 & 320 & 60 & 60 \\
\hline \multirow[t]{3}{*}{11.} & $0-1$ & $\mathrm{~S}$ & 1 & 4.2 & 0.09 & 5.0 & 850 & 290 & 50 & 40 \\
\hline & $2-3$ & $\mathrm{SC}$ & 3 & 4.9 & 0.34 & 6.1 & 2300 & 610 & 120 & 20 \\
\hline & $4-6$ & $\mathrm{C}$ & 5 & 4.9 & 0.34 & 6.1 & 2500 & 750 & 40 & 10 \\
\hline
\end{tabular}




\begin{tabular}{|c|c|c|c|c|c|c|c|c|c|c|}
\hline 1 & 2 & 3 & 4 & 5 & 6 & 7 & 8 & 9 & 10 & 11 \\
\hline \multirow{4}{*}{12.} & \multicolumn{2}{|c|}{ Plant matter } & & 4.9 & 0.07 & 22.6 & 920 & 320 & 590 & 70 \\
\hline & $0-2$ & $\mathrm{SC}$ & 3 & 4.9 & 0.26 & 16.7 & 1250 & 570 & 90 & 20 \\
\hline & $3-5$ & $\mathrm{SC}$ & 2 & 4.8 & 0.25 & 4.0 & 2250 & 860 & 40 & 20 \\
\hline & $8-10$ & $\mathrm{SC}$ & 2 & 4.8 & 0.20 & 6.5 & 1550 & 760 & 70 & 20 \\
\hline \multirow[t]{4}{*}{13.} & \multicolumn{2}{|c|}{ Plant matter } & & 4.4 & 0.09 & 12.9 & 650 & 340 & 740 & 50 \\
\hline & $2-4$ & $\mathrm{SC}$ & 4 & 4.3 & 0.34 & 6.5 & 1550 & 750 & 90 & 20 \\
\hline & $6-8$ & $\mathrm{SC}$ & 3 & 4.5 & 0.30 & 3.7 & 1150 & 880 & 10 & 20 \\
\hline & $8-10$ & C & 5 & 4.1 & 0.31 & 5.5 & 1250 & 650 & 130 & 30 \\
\hline \multirow[t]{4}{*}{14.} & \multicolumn{2}{|c|}{ Plant matter } & & 4.5 & 0.07 & 7.3 & 640 & 320 & 1230 & 70 \\
\hline & $1-3$ & $\mathrm{SC}$ & 2 & 5.0 & 0.25 & 12.3 & 3000 & 880 & 210 & 90 \\
\hline & $4-6$ & $\mathrm{SC}$ & 4 & 4.2 & 0.30 & 5.8 & 1750 & 840 & 70 & 30 \\
\hline & $8-10$ & C & 7 & 5.8 & 0.37 & 7.2 & 6700 & 3400 & 70 & 20 \\
\hline \multirow[t]{4}{*}{15.} & \multicolumn{2}{|c|}{ Plant matter } & & 4.8 & 0.09 & 5.9 & 900 & 610 & 680 & 20 \\
\hline & $1-3$ & $\mathrm{SC}$ & 2 & 4.7 & 0.38 & 8.0 & 3200 & 1060 & 210 & 40 \\
\hline & $5-6$ & $\mathrm{LC}$ & 3 & 5.0 & 0.34 & 5.5 & 2500 & 1160 & 10 & 10 \\
\hline & $8-9$ & C & 6 & 5.1 & 0.37 & 8.7 & 3000 & 1250 & 10 & 10 \\
\hline \multirow[t]{4}{*}{16.} & \multicolumn{2}{|c|}{ Plant matter } & & 4.8 & 0.09 & 8.3 & 1000 & 130 & 750 & 70 \\
\hline & $0-2$ & $\mathrm{C}$ & 3 & 4.7 & 0.30 & 5.5 & 2000 & 820 & 250 & 20 \\
\hline & $3-5$ & $\mathrm{C}$ & 3 & 4.8 & 0.25 & 5.1 & 1400 & 600 & 30 & 30 \\
\hline & $8-10$ & C & 4 & 4.9 & 0.23 & 4.2 & 1400 & 480 & 60 & 60 \\
\hline \multirow[t]{4}{*}{17.} & \multicolumn{2}{|c|}{ Plant matter } & & 5.0 & 0.11 & 10.7 & 1170 & 460 & 220 & 50 \\
\hline & $1-3$ & $\mathrm{SC}$ & 4 & 5.0 & 0.26 & 5.6 & 2500 & 900 & 60 & 20 \\
\hline & $4-6$ & & 5 & 5.2 & 0.37 & 5.5 & 4100 & 1440 & 40 & 70 \\
\hline & $8-10$ & & 6 & 5.3 & 0.40 & 5.0 & 5100 & 1840 & 30 & 50 \\
\hline \multirow[t]{4}{*}{18.} & \multicolumn{2}{|c|}{ Plant matter } & & 5.0 & 0.12 & 22.9 & 1200 & 500 & 550 & 40 \\
\hline & $1-3$ & $\mathrm{SC}$ & 3 & 5.1 & 0.26 & 16.9 & 2000 & 620 & 70 & 20 \\
\hline & $4-6$ & & 5 & 5.1 & 0.35 & 7.9 & 4200 & 700 & 50 & 70 \\
\hline & $8-10$ & & 7 & 5.2 & 0.37 & 7.4 & 7100 & 1440 & 50 & 40 \\
\hline \multirow[t]{3}{*}{19.} & $0-1$ & $\mathrm{SC}$ & 3 & 4.4 & 0.27 & 9.8 & 2800 & 700 & 90 & 10 \\
\hline & $1-3$ & $\mathrm{C}$ & 4 & 4.9 & 0.28 & 5.1 & 2200 & 620 & 10 & 10 \\
\hline & $5-7$ & C & 4 & 5.1 & 0.26 & 4.9 & 1750 & 570 & 10 & 10 \\
\hline \multirow[t]{3}{*}{20.} & $0-2$ & $\mathrm{SC}$ & 4 & 5.5 & 0.27 & 15.4 & 1800 & 400 & 30 & 10 \\
\hline & $3-5$ & $\mathrm{C}$ & 7 & 5.4 & 0.46 & 8.1 & 3100 & 650 & 20 & 10 \\
\hline & $6-8$ & $\mathrm{C}$ & 6 & 5.4 & 0.30 & 4.8 & 2300 & 780 & 10 & 10 \\
\hline \multirow[t]{3}{*}{21} & $0-2$ & $\mathrm{SC}$ & 3 & 3.6 & 0.23 & 24.4 & 760 & 970 & 280 & 120 \\
\hline & $3-9$ & & 5 & 3.5 & 0.32 & 3.5 & 1060 & 1300 & 160 & 120 \\
\hline & $10-13$ & & 7 & 4.2 & 0.40 & 13.2 & 1560 & 1430 & 100 & 290 \\
\hline \multirow[t]{3}{*}{22.} & $1-3$ & C & 3 & 4.6 & 0.21 & 4.5 & 1400 & 360 & 10 & 5 \\
\hline & $5-7$ & C & 3 & 4.2 & 0.20 & 3.1 & 1400 & 560 & 10 & 5 \\
\hline & $11-14$ & $\mathrm{LC}$ & 4 & 4.4 & 0.23 & 5.3 & 1300 & 640 & 10 & 5 \\
\hline
\end{tabular}




\begin{tabular}{|c|c|c|c|c|c|c|c|c|c|c|}
\hline 1 & 2 & 3 & 4 & 5 & 6 & 7 & 8 & 9 & 10 & 11 \\
\hline \multirow[t]{3}{*}{23.} & $0-2$ & EuSC & 3 & 4.4 & 0.18 & 18.4 & 2800 & 1150 & 550 & 160 \\
\hline & $3-5$ & & 5 & 4.7 & 0.32 & 4.9 & 6100 & 1500 & 110 & 130 \\
\hline & $8-10$ & & 7 & 4.3 & 0.38 & 5.1 & 4000 & 1800 & 90 & 120 \\
\hline \multirow[t]{3}{*}{24.} & $0-1$ & $\mathrm{BC}$ & 1 & 4.9 & 0.16 & 9.9 & 1700 & 290 & 90 & 60 \\
\hline & $2-3$ & $\mathrm{BC}$ & 2 & 5.2 & 0.24 & 15.6 & 1800 & 170 & 40 & 60 \\
\hline & $5-7$ & $\mathrm{BC}$ & 7 & 5.0 & 0.37 & 10.6 & 3000 & 540 & 10 & 140 \\
\hline \multirow[t]{3}{*}{25.} & $0-2$ & $\mathrm{BC}$ & 1 & 5.5 & 0.14 & 9.0 & 2900 & 310 & 100 & 110 \\
\hline & $3-5$ & $\mathrm{BC}$ & 3 & 5.2 & 0.28 & 7.5 & 4800 & 620 & 170 & 160 \\
\hline & $7-9$ & $\mathrm{BC}$ & 7 & 5.3 & 0.34 & 4.4 & 4600 & 500 & 110 & 100 \\
\hline
\end{tabular}

ride. It is known to be a less effective exchanger in peat soils than barium chloride and it appears to be able to dissolve some calcium sulphate. On the other hand, it may be possible that the amounts of cations extracted by any solvent from the air-dried and ground samples markedly differ from those exchangeable from fresh samples. In any case, the results obtainable by the method employed probably yield a rough estimate of the fairly easily available amounts of calcium, magnesium and potassium in the peat samples. Since more attention was paid to the relative contents than on the absolute amounts it did not appear to be desirable to use any constant coefficient to improve the possibly too low results obtained by using only one extraction.

\section{Results}

The data in Table 1 show that the kind of peat in the various layers of the same peat land is almost equal or only slightly tends to improve with the depth. Generally the degree of humification and the volume weight increase on going deeper but changes in the $\mathrm{pH}$ values are fairly small and irregular. The ash content of all the samples is rather low indicating no marked presence of mineral matter in these virgin peat soils.

The amounts of the extractable cations are reported as kilograms per hectare in a layer of $2 \mathrm{dm}$. Thus, the markedly varying volume weight of the samples was taken into consideration and the comparison of the cation content could occur on a basis better corresponding to the natural conditions than if the results were presented per weight. These values are, of course, somewhat artificial, since volume weights estimated on air-dry and ground peat are used for the calculation, but they can be supposed to give a fairly reliable picture of the relative amounts of the extractable cations in the different layers.

In almost all the samples calcium appears to be the dominating cation, although also the content of magnesium may often be of the same order. The potassium and sodium contents of the peat samples are far lower and, on the average, nearly equal to each other. Only in samples of undecomposed plant material the potassium content, even when expressed on the volume basis, can be higher than the calcium and magnesium contents of the respective samples. 
Table 2. The relative contents of extractable cations in various depths of the peat lands.

\begin{tabular}{|c|c|c|c|c|c|c|c|c|c|c|}
\hline \multirow{2}{*}{ No } & \multirow{2}{*}{$\begin{array}{l}\text { Depth } \\
\text { dm }\end{array}$} & \multirow{2}{*}{$\begin{array}{c}\text { Kind } \\
\text { of } \\
\text { peat }\end{array}$} & \multicolumn{4}{|c|}{ Per volume } & \multicolumn{4}{|c|}{ Per weight } \\
\hline & & & $\mathrm{Ca}$ & $\mathrm{Mg}$ & K & $\mathrm{Na}$ & $\mathrm{Ca}$ & $\mathrm{Mg}$ & K & $\mathrm{Na}$ \\
\hline \multirow[t]{3}{*}{1.} & $0-3$ & $\mathrm{~S}$ & 100 & 100 & 100 & 100 & 100 & 100 & 100 & 100 \\
\hline & $4-6$ & $\mathrm{~S}$ & 115 & 85 & 40 & 30 & 115 & 85 & 40 & 35 \\
\hline & $6-8$ & $\mathrm{CS}$ & 330 & 250 & 100 & 55 & 105 & 80 & 30 & 15 \\
\hline \multirow[t]{3}{*}{2.} & $0-2$ & $\mathrm{~S}$ & 100 & 100 & 100 & 100 & 100 & 100 & 100 & 100 \\
\hline & $2-4$ & $\mathrm{CS}$ & 185 & 110 & 120 & 500 & 90 & 55 & 55 & 200 \\
\hline & $4-6$ & $\mathrm{CS}$ & 160 & 90 & 50 & 125 & 70 & 40 & 20 & 50 \\
\hline \multirow[t]{3}{*}{3.} & $1-2$ & $\mathrm{~S}$ & 100 & 100 & 100 & 100 & 100 & 100 & 100 & 100 \\
\hline & $2-3$ & $\mathrm{~S}$ & 150 & 150 & 120 & 120 & 95 & 100 & 80 & 80 \\
\hline & $3-4$ & $\mathrm{CS}$ & 200 & 185 & 90 & 80 & 55 & 50 & 25 & 25 \\
\hline \multirow[t]{3}{*}{4.} & $0-3$ & $\mathrm{LCS}$ & 100 & 100 & 100 & 100 & 100 & 100 & 100 & 100 \\
\hline & $3-5$ & & 210 & 190 & 70 & 1700 & 75 & 70 & 25 & 560 \\
\hline & $7-10$ & & 210 & 210 & 30 & 750 & 50 & 55 & 5 & 170 \\
\hline \multirow[t]{4}{*}{5.} & $0-2$ & $\mathrm{~S}$ & 100 & 100 & 100 & 100 & 100 & 100 & 100 & 100 \\
\hline & $2-5$ & & 230 & 150 & 45 & 75 & 130 & 80 & 20 & 40 \\
\hline & $5-9$ & & 400 & 230 & 55 & 125 & 95 & 55 & 15 & 30 \\
\hline & $9-11$ & & 630 & 390 & 65 & 65 & 100 & 60 & 10 & 10 \\
\hline \multirow[t]{4}{*}{6.} & \multicolumn{2}{|c|}{ Plant matter } & 30 & 30 & 330 & 600 & 120 & 135 & 1400 & 2300 \\
\hline & $0-2$ & S & 100 & 100 & 100 & 100 & 100 & 100 & 100 & 100 \\
\hline & $3-5$ & $\mathrm{~S}$ & 85 & 60 & 20 & 140 & 70 & 50 & 20 & 100 \\
\hline & $8-10$ & $\mathrm{SC}$ & 65 & 40 & 15 & 0 & 60 & 40 & 10 & 0 \\
\hline \multirow[t]{4}{*}{7.} & \multicolumn{2}{|c|}{ Plant matter } & 60 & 55 & 3100 & 400 & 115 & 110 & 6500 & 900 \\
\hline & $0-3$ & S & 100 & 100 & 100 & 100 & 100 & 100 & 100 & 100 \\
\hline & $5-7$ & $\mathrm{CS}$ & 200 & 190 & 60 & 200 & 80 & 75 & 25 & 75 \\
\hline & $8-10$ & $\mathrm{CS}$ & 260 & 240 & 140 & 70 & 90 & 85 & 50 & 25 \\
\hline \multirow[t]{3}{*}{8.} & \multicolumn{2}{|c|}{ Plant matter } & 50 & 85 & 530 & 210 & 155 & 280 & 1760 & 730 \\
\hline & $1-3$ & CS & 100 & 100 & 100 & 100 & 100 & 100 & 100 & 100 \\
\hline & $3-5$ & $\mathrm{SC}$ & 90 & 100 & 45 & 60 & 70 & 75 & 35 & 50 \\
\hline \multirow[t]{3}{*}{9.} & \multicolumn{2}{|c|}{ Plant matter } & 35 & 40 & 170 & 150 & 140 & 160 & 680 & 500 \\
\hline & $0-2$ & $\mathrm{~S}$ & 100 & 100 & 100 & 100 & 100 & 100 & 100 & 100 \\
\hline & $3-5$ & $\mathrm{C}$ & 70 & 65 & 30 & 100 & 70 & 65 & 30 & 75 \\
\hline \multirow[t]{3}{*}{10.} & \multicolumn{2}{|c|}{ Plant matter } & 35 & 100 & 320 & 65 & 130 & 380 & 1210 & 240 \\
\hline & $1-3$ & $\mathrm{SC}$ & 100 & 100 & 100 & 100 & 100 & 100 & 100 & 100 \\
\hline & $3-5$ & LC & 70 & 90 & 25 & 30 & 80 & 100 & 30 & 35 \\
\hline \multirow[t]{3}{*}{11.} & $0-1$ & $\mathrm{~S}$ & 100 & 100 & 100 & 100 & 100 & 100 & 100 & 100 \\
\hline & $2-3$ & $\mathrm{SC}$ & 270 & 210 & 240 & 35 & 70 & 55 & 60 & 100 \\
\hline & $4-6$ & $\mathrm{C}$ & 290 & 260 & 80 & 15 & 80 & 70 & 20 & 50 \\
\hline
\end{tabular}




\begin{tabular}{llllllllllll}
\hline 1 & 2 & 3 & 4 & 5 & 6 & 7 & 8 & 9 & 10 & 11
\end{tabular}

12. Plant matter

$0-2 \quad \mathrm{SC}$

$3-5 \quad \mathrm{SC}$

$8-10 \quad \mathrm{SC}$

13. Plant matter

$2-4 \quad \mathrm{SC}$

4-6 SC

$8-10 \quad \mathrm{C}$

14. Plant matter

$1-3 \quad \mathrm{SC}$

4-6 SC

$8-10 \quad$ C

15. Plant matter

$1-3 \quad$ SC

$5-6 \quad$ LC

$8-9 \quad \mathrm{C}$

16. Plant matter

$0-2 \quad \mathrm{C}$

$3-5 \quad \mathrm{C}$

$8-10 \quad \mathrm{C}$

17. Plant matter

$1-3 \quad$ SC

$4-6$

$8-10$

18. Plant matter

$1-3 \quad$ SC

$4-6$

$8-10$

19. $0-1 \quad \mathrm{SC}$

$1-3 \quad \mathrm{C}$

$5-7 \quad \mathrm{C}$

20. $\quad 0-2 \quad \mathrm{SC}$

$3-5 \quad \mathrm{C}$

$6-8 \quad \mathrm{C}$

21. $0-2 \quad \mathrm{SC}$

$3-9$

$10-13$

22. $1-3 \quad \mathrm{C}$

$5-7 \quad \mathrm{C}$

$11-14 \quad$ LC

$\begin{array}{rrrr}75 & 55 & 650 & 440 \\ 100 & 100 & 100 & 100 \\ 180 & 150 & 45 & 125 \\ 125 & 135 & 80 & 125 \\ & & & \\ 40 & 45 & 820 & 250 \\ 100 & 100 & 100 & 100 \\ 75 & 120 & 15 & 100 \\ 80 & 85 & 145 & 125\end{array}$

$\begin{array}{lll}20 & 35 & 590\end{array}$

100

60

100

390

\section{0}

100

60

100

80

95

110

120

$50 \quad 80 \quad 350$

$100 \quad 100 \quad 100$

55

55

75

65

$50 \quad 50$

100

50
100

165

205

160

205

$\begin{array}{rrr}60 & 80 & 790 \\ 100 & 100 & 100\end{array}$

$210 \quad 115$

355

230

70

70

$100 \quad 100$

$80 \quad 90$

100

10

65

80

$100 \quad 100$

$170 \quad 160$

$130 \quad 195$

$\begin{array}{rr}100 & 100 \\ 70 & 100 \\ 40 & 60\end{array}$

$\begin{array}{llll}100 & 100 & 100 & 100\end{array}$

$140 \quad 135$

$55 \quad 100$

210

145

35

240

$\begin{array}{llll}100 & 100 & 100 & 100\end{array}$

$\begin{array}{llll}100 & 155 & 90 & 100\end{array}$

$\begin{array}{llll}95 & 180 & 110 & 100\end{array}$

100

170

250

100

200

$\begin{array}{rrrr}280 & 210 & 2340 & 1600 \\ 100 & 100 & 100 & 100 \\ 190 & 150 & 45 & 125 \\ 160 & 170 & 85 & 165\end{array}$

$\begin{array}{rrrr}155 & 175 & 3160 & 970 \\ 100 & 100 & 100 & 100 \\ 85 & 120 & 15 & 100 \\ 85 & 95 & 160 & 135\end{array}$

$\begin{array}{rrrr}75 & 130 & 2140 & 300 \\ 100 & 100 & 100 & 100 \\ 50 & 80 & 25 & 30 \\ 150 & 260 & 20 & 20\end{array}$

$\begin{array}{rrrr}115 & 240 & 1350 & 260 \\ 100 & 100 & 100 & 100 \\ 80 & 120 & 5 & 20 \\ 95 & 120 & 5 & 20\end{array}$

$$
170
$$

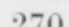

100

$270 \quad 1200 \quad 720$

70

$100 \quad 100$

100

$\begin{array}{llll}70 & 90 & 20 & 120\end{array}$

$\begin{array}{llll}75 & 90 & 35 & 220\end{array}$

\section{0}

120

100

120
100

900

550

115

110

100

100

130

130

45

225

130

$$
175
$$

$\begin{array}{llll}130-175 & 1750 & 380\end{array}$

100

$100 \quad 100$

100

$\begin{array}{llll}160 & 85 & 55 & 250\end{array}$

250

160

55

150

$$
100
$$$$
100
$$

$\begin{array}{rrrr}100 & 100 & 100 & 100 \\ 75 & 85 & 10 & 15 \\ 65 & 85 & 5 & 15\end{array}$

6.

$\begin{array}{rrrr}100 & 100 & 100 & 100 \\ 100 & 95 & 30 & 50 \\ 115 & 175 & 30 & 50\end{array}$




\begin{tabular}{|c|c|c|c|c|c|c|c|c|c|c|}
\hline 1 & 2 & 3 & 4 & 5 & 6 & 7 & 8 & 9 & 10 & 11 \\
\hline \multirow[t]{3}{*}{23.} & $0-2$ & EuSC & 100 & 100 & 100 & 100 & 100 & 100 & 100 & 100 \\
\hline & $3-5$ & & 220 & 130 & 20 & 80 & 125 & 70 & 10 & 50 \\
\hline & $8-10$ & & 140 & 155 & 15 & 75 & 70 & 75 & 10 & 40 \\
\hline \multirow[t]{3}{*}{24.} & $0-1$ & $\mathrm{BC}$ & 100 & 100 & 100 & 100 & 100 & 100 & 100 & 100 \\
\hline & $2-3$ & $\mathrm{BC}$ & 105 & 60 & 45 & 100 & 70 & 40 & 30 & 70 \\
\hline & $5-7$ & $\mathrm{BC}$ & 175 & 185 & 10 & 230 & 75 & 80 & 5 & 100 \\
\hline \multirow[t]{3}{*}{25.} & $0-2$ & $\mathrm{BC}$ & 100 & 100 & 100 & 100 & 100 & 100 & 100 & 100 \\
\hline & $3-5$ & $\mathrm{BC}$ & 165 & 200 & 170 & 145 & 80 & 100 & 90 & 70 \\
\hline & $7-9$ & $\mathrm{BC}$ & 160 & 160 & 110 & 100 & 65 & 65 & 45 & 40 \\
\hline
\end{tabular}

In peat lands of better quality the amount of extractable calcium tends to be somewhat higher than that of the peat lands of lower quality. The corresponding differences in the contents of other cations seem to be less marked.

Considerable variations exist in the distribution of calcium in different layers of the peat soils. Generally, an increase in the calcium content with the depthcan be noted. The same seems also to hold true with the magnesium extracted by this procedure, but the distribution of potassium is reverse. Particularly the potassium content of undecomposed plant material appears to be far higher than that of the lower peat layers. The distribution of sodium seems to be less regular.

The general trends in the distribution of the extractable cations in various depths may be easier to observe if instead of the absolute amounts the relative contents are examined. Therefore, the cation contents of the surface samples were given the value of 100 , and the respective relative values for the otherlayers were calculated. These results are listed in Table 2 .

The relative calcium and magnesium contents calculated on the basis of the $\mathrm{kg} / \mathrm{ha}$-values seem most often to increase with the depth, although there also are profiles in which the surface layer appears to be the richest one. In most of the cases potassium is concentrated in the surface vegetation and also the surface layer of peat generally contains a higher amount of extractable potassium than the lower ones. The distribution of sodium in some profiles resembles that of potassium, whereas in other cases an increase in the sodium content with increasing depth may be found.

If the relative values calculated on the basis of the cation content expressed per weight are examined the concentration of potassium and sodium in plant matter is the most striking feature. Also the magnesium content in all the cases and the calcium content in most of them are highest in the surface vegetation. Generally, the potassium content is very low in the deeper layers, but the distribution of the other cations appears to be fairly variable in the different profiles.

An approximate general view of these results may be presented by the average values of the respective relative cation contents in various layers. Owing to the fact that the sampling depths were not equal in all the peat lands only a rough 
estimation can be gained. The relative distribution of the extractable cations in four peat layers and fresh plant material appears, on the average, to be the following:

\begin{tabular}{crrrrrrrr} 
& \multicolumn{3}{c}{ Per volume } & \multicolumn{4}{c}{ Per weight } \\
& $\mathrm{Ca}$ & $\mathrm{Mg}$ & $\mathrm{K}$ & $\mathrm{Na}$ & $\mathrm{Ca}$ & $\mathrm{Mg}$ & $\mathrm{K}$ & $\mathrm{Na}$ \\
Plant material & 40 & 60 & 690 & 240 & 140 & 200 & 2030 & 790 \\
$0-3 \mathrm{dm}$ & 100 & 100 & 100 & 100 & 100 & 100 & 100 & 100 \\
$3-6 \mathrm{dm}$ & 150 & 130 & 60 & 200 & 110 & 80 & 30 & 100 \\
$6-10 \mathrm{dm}$ & 170 & 170 & 50 & 140 & 100 & 110 & 40 & 80 \\
$10-14 \mathrm{dm}$ & 310 & 240 & 70 & 140 & 100 & 100 & 40 & 80
\end{tabular}

The effect of depth on the relative amounts of extractable cations was also studied by computing the correlation coefficients between these quantities. The 12 samples of plant material were excluded, and only the peat layers were examined. The following total correlation coefficients were obtained for the depth and the relative content of cations:

$\begin{array}{ll} & \text { Cation content per volume } \\ \mathrm{Ca} & \mathrm{r}=0.22 \\ \mathrm{Mg} & \mathrm{r}=0.54^{* * *} \\ \mathrm{~K} & \mathrm{r}=-0.27 * \\ \mathrm{Na} & \mathrm{r}=0.09\end{array}$

$$
\begin{aligned}
& \text { Cation content per weight } \\
& \qquad \begin{aligned}
\mathrm{r} & =0.18 \\
\mathrm{r} & =0.30^{*} \\
\mathrm{r} & =-0.48^{* * *} \\
\mathrm{r} & =0.04
\end{aligned}
\end{aligned}
$$

According to these figures no correlation exists between the depth and the content of extractable calcium or sodium in these peat lands. The correlation coefficients between the depth and the magnesium content appear to be somewhat higher than could have been expected on the basis of the average values reported above, particularly if the data concerning the magnesium content per weight are examined. The negative correlation between the content of extractable potassium and the depth is distinct, although not very close.

\section{Discussion}

The results reported in this paper do not reveal any clear picture of the distribution of plant-available cations in various depths of virgin peat lands. The only distinct feature seems to be the accumulation of extractable potassium in the living surface vegetation and also, although in a less degree, in the surface layers of peat. Almost in every case, also the percentic content of sodium, magnesium, and calcium in the surface vegetation was somewhat higher than that of the peat below.

The accumulation of the easily extractable potassium in surface vegetation may be taken to arise from the scanty occurrence of this important plant nutrient in peat lands. Since it was found that also in the peat layers almost all of the total potassium was extractable by $1 \mathrm{~N}$ ammonium chloride, there is probably no reason to suppose that potassium would be markedly more tenaceously adsorbed in the lower and more humified peat layers than in the plant material and in the surface layers. 
Of course, the possibility of the washing out of potassium from the lower layers of peat lands can not be excluded. On the basis of the present material it is impossible to conclude which of these phenomena, the most economical utilization of the poor sources of potassium in the peat lands or the washing out of this nutrient, is the more important one. According to the opinion of the authors, the former reason seems to be more probable than the latter one.

If the potassium content of the surface layers of these peat lands is compared to the uptake of this nutrient by a medium crop of oats or timothy, it will be found that most of these peat lands contain enough easily available potassium for the growth of one or two crops. However, there are peat lands, such as the numbers $1,7,20$ and 22 in which the lack of available potassium probably prevents the growth of a satisfactory crop. If the amounts of calcium and magnesium extracted by the present method are available for plants, these nutrients do not generally play the role of minimum factors in peat soils.

\section{Sum $m$ ary}

It has been attempted in the present paper to study the distribution of plantavailable calcium, magnesium, and potassium in various depths of 25 virgin peat lands. The amounts of these cations extractable by $1 \mathrm{~N}$ ammonium chloride are supposed to give a rough estimation on the available content of the nutrients. Also the quantities of extracted sodium are reported.

It has been found that the percentic content of these cations in the surface vegetation are higher than in the peat. Particularly marked is the accumulation of potassium in living plants and, although in a less degree, in the surface layers of peat. The variation in the distribution of the extractable amounts of the cations in various depths of the peat lands is considerable. A significant correlation exists between the depth and the magnesium content, and a negative correlation between the depth and the amount of extractable potassium.

So far as the amount of cations extracted by $1 \mathrm{~N}$ ammonium chloride represents nutrients available for plants, calcium and magnesium are not generally minimum factors in peat soils, whereas in most soils the sources of potassium probably will be depleted by the first crops.

\section{REFERENCES}

(1) Cheng, K. L. \& BRAy, R. H. 1951: Determination of calcium and magnesium in soil and plant material. Soil Sci. 72: 449-458.

(2) Kaila, A. 1956. Phosphorus in various depths of some virgin peat lands. J. Sci. Agric. Soc. Finland 28: $90-104$

(3) Post, L. von 1924. Das genetische System der organogenen Bildungen Schwedens. Com. Intern. Pédol. IV Comm. 22: 287-304.

(4) Waren, H. 1924. Untersuchungen über die botanische Entwicklung der Moore. Wiss. Veröff. Finn. Moorkulturver. No 5. Helsinki. 
S E L O S T U S :

\title{
UUTTUVAN KALSIUMIN, MAGNESIUMIN, KALIUMIN JA NATRIUMIN MÄ̈̈RISTÄ ERÄITTEN LUONNONTILAISTEN SOITTEN ERI SYVYYKSISSÄ
}

\author{
Armi Kaila ja JaAKKo Kivekäs
}

Yliopiston maanviljelyskemian laitos, Helsinki

Tutkimuksessa on esitetty $1 \mathrm{n}$ ammonium kloridin uuttamat kalsiumin, magnesiumin, kaliumin ja natriumin määrät 25 luonnontilaisen suon eri kerroksista pinnasta noin 1 m:n syvyyteen. Lisäksi analysoitiin 12 suon pintakasvustoa.

Todettiin kasvien sisältävän enemmän uuttuvia kationeja kuin alla olevan turpeen. Etenkin kasviaineksen kaliumin pitoisuus oli erittäin suuri verrattuna turpeen vastaavaan arvoon. Turpeen uuttuvan kaliumin määrä aleni tavallisesti syvemmälle mentäessä, mutta muitten kationien kohdalla muutokset olivat epäsäännöllisempiä. Uuttuvan magnesiumin pitoisuus näytti lisääntyvän syvemmissä kerroksissa.

Sikäli kuin saadut tulokset kuvastavat soitten käyttökelpoisia ravinnevarastoja, näyttää siltä, että kalsium ja magnesium vain harvoin ovat minimitekijöinä. Kalium sen sijaan riittänee tavallisesti tyydyttämään vain ensimmäisten satojen tarpeen. 